\title{
Managing Expatriates: Analyzing the Experience of an Internationalized Brazilian Company
}

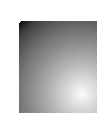

\author{
Gestão de Expatriados: analisando a experiência de uma \\ empresa brasileira internacionalizada
}

\begin{abstract}
Bernardo Meyer
Professor do Departamento de Ciências da Administração. Universidade Federal de Santa Catarina. Florianópolis, Santa Catarina, Brasil.E-mail: bernardo.meyer@ufsc.br
\end{abstract}

\section{Victor Meyer Jr.}

Professor do Programa de Mestrado e Doutorado em Administração. Pontifícia Universidade Católica do Paraná. Curitiba, Paraná, Brasil.E-mail: victormeyerjr@gmail.com

Kamila Vieira da Silva

Bacharel em Administração - Pesquisadora. Centro Universitário Estácio de Sá de Santa Catarina. São José, Santa Catarina, Brasil. E-mail: kamila_vs@hotmail.com

\section{Larissa Mallmann Fernandes Almeida Brandão}

Mestre em Administração - Pesquisadora. Pontifícia Universidade Católica do Paraná. Curitiba, Paraná, Brasil.

E-mail: laramallmann@hotmail.com

\section{Abstract}

The management of expatriate employees is an important topic in the field of international business. Most of the studies on expatriation management are based on the experience of North American and Western European corporations. Few studies focus on corporations from developing countries. The purpose of this study was to examine how expatriates were managed by a Brazilian multinational corporation in relation to the cultural dimension. This is a single case study based on qualitative research. The focus was a Brazilian telecommunications company operating in China. The research investigated the preparedness of expatriates prior to departure and the kinds of difficulties they faced in daily life abroad. The analysis revealed that the lack of preparation of expatriates before departure was an important barrier to overcome in order to achieve better performance. The findings indicated that psychic distance was the key factor responsible for major problems facing expatriate workers.

Keywords: Internationalization. Expatriates. Management.

\section{Resumo}

A gestão de empregados expatriados é um tema importante nos negócios internacionais. A maior parte dos estudos de gestão de expatriados é baseada na experiência de empresas norte-americanas e da Europa Ocidental. Poucos são os estudos focados na experiência de empresas de países em desenvolvimento. O objetivo do trabalho é examinar como a gestão de expatriados é conduzida por uma empresa brasileira, com ênfase nos aspectos culturais. Trata-se de estudo de caso centrado em pesquisa qualitativa em uma empresa brasileira do ramo de telecomunicações que opera na China. A pesquisa observou a preparação dos expatriados antes de sua saída do país e as dificuldades enfrentadas em seu dia a dia no exterior. A análise revelou que a falta de reparação dos expatriados é uma importante fonte de dificuldades que precisa ser gerenciada e resolvida para se atingir melhor desempenho.

Palavras-chave: Internacionalização. Expatriados. Gestão. 


\section{INTRODUCTION}

The management of expatriate employees has been an important subject of research in the field of international business. The challenges facing corporate employees sent on international missions have aroused academic curiosity and resulted in attempts to measure the effectiveness of this human resource policy.

Most of the studies conducted on expatriation management are based on the experience of large North American and West European corporations. Little research work as focused on the reality of corporations from developing countries. Few studies have been conducted on expatriate management in Brazilian companies operating overseas and focused on the cultural challenges facing their executives. Most expatriate management studies in Brazil are based on foreign executives working in the country (DOMINGUES; BUENO, 2008).

Brazilian companies are late movers in the international markets. However nowadays several are developing plants and operations overseas to take advantage of the opportunities created by the global markets. Among the countless challenges faced by these companies is preparing their employees to adjust to new cultures and seek high performance overseas.

The purpose of this paper was to examine how the management of expatriates is handled by a Brazilian multinational corporation, with a special focus on cultural aspects. By examining a single in-depth case, with qualitative characteristics, the study aims to gauge how well prepared expatriates are prior to departure and the kinds of difficulties they face when they come up against day-to-day life in China.

The relevance of this study is based on the importance of the growing international business relations between Brazil and China. Since 2009, when China overtook the United States of America as Brazil's major trading partner, many Brazilian corporations have begun setting up operations in China. A significant psychic distance between the two countries represented a major obstacle to the adaptation of expatriate executives.

\section{Managing Expatriates}

The increase in international operations by multinational corporations has led to an increase in the number of expatriate employees all over the world. Expatriates are used to implementing the internationalization of their organizations in foreign subsidiaries successfully (BLACK, 1988).

Managing expatriates is not an easy task, since it usually means high costs and considerable preparation. High cost is indeed one of the major problems associated with expatriate management (MCNULTY; DE CIERI; HUTCHINGS, 2009). For companies with hundreds of expatriates, the total cost can easily reach several million dollars (BLACK, 1988, p. 278). This is because expatriated employees end up receiving high salaries and benefits to be relocated to another foreign subsidiary.

Most expatriates are satisfied with their international assignments, although they do complain that their companies do not have repatriation programs and policies in place (TUNG, 1998). According to the author, the positive impact of expatriation has a great deal to do with the positive influence it will have on career advancement.

In order to develop effective expatriate management to avoid major problems it is necessary to plan three strategic actions (CHEW, 2004). The first focuses on selecting the right people to work as expatriates on overseas assignments. The second is related to preparing selected employees to face their challenge abroad. Finally, the third deals with the preparation of a return policy for when expatriates are brought back to their home country.

Many authors have mentioned ways of mitigating problems related to expatriate management. Black (1988), Black and Mendenhall (1990), Tung (1998) and Shaffer, Harrison, Gregersen, Black and Ferzandi (2006), for example, suggest that companies that provide training and education regarding the host country prior to departure might facilitate the adaptation of expatriates. This is especially true if this role implies interaction with host nationals.

The lack of information and knowledge concerning foreign contexts also adds complexity to 
expatriate management. Consequently, preparation for expatriation is an important task since it helps to anticipate many situations that might arise during the process (HOFSTEDE, 1980; DUNBAR; KATCHER, 1990). Nevertheless, many organizations continue to neglect this issue and do not prepare their employees appropriately for their tasks overseas. The outcomes are unexpected issues to be handled by managers abroad that are triggered due to the unpreparedness of companies to act in new cultural and economic contexts.

The three strategic actions, selecting, preparing and developing a return policy, are a road map for a well-planned, organized and effective expatriation program. Problems and crises involving expatriates have a high cost for an organization, first because it can threaten the organization's assets and image in the host country, and second because they can lead to the loss of an important organizational asset: its valued expatriates (CHEW, 2004).

The success or failure of expatriation programs cannot be linked only to internal problems, but also to external factors. Cultural, economic and social elements can be listed as relevant external factors that have some influence over expatriates. These external factors exert an influence not only on expatriates, but also on their families (HOFSTEDE, 1980).

In a study of human resource managers from Australian firms, Chew (2004) found that the main reason behind the failure of expatriates on overseas assignments had to do with their families. The inability of the expatriate's family to adapt to the new reality in a foreign country was a major factor in the employees' failure in their duties (ANDREASON, 2008; COLE, 2011; HARVEY; NAPIES; MOELLER, 2009; KUPKA; CATHRO, 2007; SHAFFER; HARRISON, 1998; HARVEY, 1998).

To analyze expatriate performance, it is necessary to adopt a broad approach considering not only the technical but also the social and psychological factors that influence the day-to-day life of employees, which characterizes it as a multidimensional factor (CALIGIURI; TUNG, 2001)

Expatriation is considered relevant to organizations with an international presence, since it enriches the experience of managers and helps the company to maintain control and improve performance in foreign operations by placing committed high performing employees in key positions abroad. All these factors combined help the company to achieve a higher performance level.

Expatriation also enriches the experience of employees, taking them into a new learning process that will benefit the organization. Employees with cross-cultural experience are also likely to assist their organizations better, particularly helping those in emerging economies, to integrate into the global market, learn new technologies and provide legitimacy. These employees may be perceived as having personality characteristics that facilitate the achievement of these objectives (ZOOGAH; ABBEY, 2010).

The use of expatriate managers was found to be greater when the parent company had longer periods of experience in the host market, according to a study conducted in Japanese multinational corporations (DELIOS; BJORKMAN, 2000). On the other hand, the research conducted by Tan and Mahooney (2006) and Ando (2011) showed the reverse, with the number of expatriate managers being reduced as the company gained more experience in the local market.

\section{Culture and International Business}

As organizations go global, they bring in employees not only from their host countries but from other countries in which they operate. Consequently, multinational companies have employees of various nationalities and cultural backgrounds working and managing operations in different countries. This mixture results in professional, cultural and social challenges. The gaps derived from these differences become great obstacles to individuals and companies achieving the performance expected of them in a different context. Despite the difficulties faced by expatriate managers operating across cultures, relatively few companies appear to offer cross-cultural training (BLACK; MENDENHALL, 1990).

Culture tends to be something invisible abroad, disseminated in both individual and group behavior (BRANNEN; THOMAS, 2010). To Hofstede (1980, p. 13), culture is a "collective programing of minds". Managers, when crossing countries' frontiers with the frequency observed today, need to pay attention to the countries' and organizations' cultural dimension with 
which they interact to avoid the risk of seeing their work compromised (MEYER; MEYER; MURPHY, 2006). On this matter, Dong and Liu (2010, p. 224) stated that:

Culture acts as an external source of influence on employee behaviors, on daily personal lives which consequently influences each person's behavior within the organization, since each person brings another piece of the "outside world" into the workplace.

Shih, Chiang and Hsu (2010) and Pattie and Parks (2011) point out that the lack of adjustment to local culture heralds a low performance effect for expatriates. On the other hand, after studying a multinational company's expatriates in 51 countries, Tung (1998) found that the host country's cultural difference and economic disparity did not affect the performance of foreign managers. This result might be explained by the fact that many of the interviewed managers were bilingual or multilingual expatriates. Furthermore, many of them had already spent extended periods abroad. These factors might have minimized the effect of culture on expatriate performance.

By describing the internationalization process of a Brazilian engineering firm in Angola, Francisco (2004) identified evidence that the cultural similarity was a strategic element to the success of the Brazilian foreign venture. However, problems related to war and political turmoil in the African country's recent past led the Brazilian corporation to adapt several processes and strategies to adjust to these new circumstances.

These mixed results are directly related to the capacity to adjust to different foreign cultures, which is based on the employee's knowledge and prior experience and the company's level of preparation. Thus, the proper selection of employees with the desired skills and characteristics, in conjunction with some prior company preparation, might be effective in terms of combatting cultural shocks. In international human resource management, each country and culture needs to be analyzed individually, since there is no standardized global solution (ROWLEY; BENSON, 2002).

Brazilian culture is described as one that is well adjusted to expatriate experiences. Its executives adjust to foreign culture more easily since Brazilians are described as friendly, flexible, patient, happy people who easily adapt to changes (DOMINGUES; BUENO, 2008).
These characteristics attributed to Brazilian culture are not a guarantee of success, especially when executives do not take local culture into consideration. The internationalization of the Brazilian educational group Estácio de Sá is an example of how an ethnocentric approach adopted by Brazilian expatriate managers working in Paraguay brought operational difficulties to its foreign venture (MEYER; MEYER; KRETZER-SANTOS, 2009).

In international business, the concept of psychic distance is quite relevant because it encompasses all factors that serve as barriers to the flow of information from one country to another. Among these factors, it is worth mentioning language, education, administrative practices, development and culture (JOHANSON; VAHLNE, 1977). Therefore, psychic distance can either facilitate or impose barriers to international business activities.

Chinese culture, with its roots in Confucianism, emphasizes that individual identities are defined as part of a network of relations with other people. After China joined the World Trade Organization, in December 2001, the country was exposed to Western values, beliefs, and customs more frequently. As a result, modern Western values started to gain acceptance, and the country began to learn more intensively to get used to interaction with foreigners (PAN; SONG; GOLDSCHIMIDT; FRENCH, 2010).

The success of today's complex organizations relies increasingly on the transfer and sharing of information, knowledge and the practices of people, based on technology and overcoming geographical, organizational and cultural boundaries. As collaboration, communication, and trust building gain importance, and as flows of knowledge and processes become increasingly more critical success factors, the role of individuals in mediating between and within cultures has become vital for organizational performance (BRANNEN; THOMAS, 2010).

\section{Methodology}

The research was based on an in-depth single case study with qualitative characteristics. The unit of analysis was the Intelbras office in China 
The case study research strategy enables researchers to combine different research methods, enabling a stronger analysis of the different elements that are active in an organizational context, and are important when it comes to developing a more accurate understanding of the phenomena in question (GODOY, 2007; CRESWELL, 2009). Case studies also reveal characteristics, facts and activities of the real day-to-day life of organizations (REMENYI; WILLIAMS; MONEY; SWARTZ, 1998).

The research was conducted over a period of three (3) months, from October to December 2011. The researchers conducted a total of four in-depth interviews, which represented the total number of expatriates working in China at the time the research was developed. The interviews with the four (4) expatriate managers living abroad were conducted via skype and $e$-mail with the use of a semi-structured questionnaire.

One of the advantages of qualitative case studies is that the methodology allows the researcher to combine different research techniques and triangulate the data, thereby enriching the analysis (YIN, 2003). Triangulation is also important as it increases the validity and credibility of the data (EISENHARDT, 1989; YIN, 2003).

In addition to the interviews, two other important sources of information were used to obtain data: (a) direct non-participant observation; and (b) internal company documents. The access to all these sources was facilitated as one of the researchers had the opportunity to engage in direct non-participant observation at the company, dealing specifically with the expatriated managers over a period of six months. Direct non-participant observation enabled the researchers to obtain descriptive data and facts pertaining to the real life of the organization (JACCOUD; MEYER, 2008). The documents used in the study were mainly reports and presentations made for and by the expatriated employees. The observation, access to company documents and information collected were extremely important sources for the analysis.

\section{The CASe}

Intelbras, was founded in 1976 and is a leading Brazilian corporation in the production of telecommunications equipment, located in the metropolitan area of Florianopolis, in the south of Brazil. The company employs over 2300 workers divided into five different producing facilities.

The company is a late mover in the international markets, since only recently did it begin importing components and exporting its products. Indeed, it was only in 2003 that it established its first overseas office, located in Hong Kong. In 2006, the company moved its office to Shenzhen, in the south of China. The office is mainly responsible for purchasing, controlling the quality of the company's suppliers, researching and developing new products and logistics. In 2008, Intelbras sent its first expatriated employees to the People's Republic of China. At the time of the present study, there were four Brazilian expatriates working alongside 22 local employees.

The company's choice was determined by two main factors: first, the openness of the company to the study by allowing access to data, and second, the relevant role played by the company in the Brazilian market for telecommunications hardware, with significant exports to Latin American countries.

\section{Analysis}

The profile of the expatriate, the focus of this study, is presented in Table 1 . All the interviewees are male, with an average age of 30 years, and have been employees of the organization for about one year and a half. The expatriation experience in the organization typically lasts from two to three years. The longest experience with expatriation has been three and a half years. It is interesting to note that one of the expatriates was hired by the company specifically to be an expatriate, and has been working in the organization for the shortest period, in contrast with the company's other expatriates. Two of the four interviewees had already had prior experience as expatriates while working for other companies.

In the beginning, the expatriates were sent to Hong Kong due to favorable taxation issues. However, nowadays they are being sent to Shenzhen, in mainland China, where the company currently has an office that oversees the purchase of components in China and other South-East Asian countries, such as Taiwan, South Korea, Hong Kong and Vietnam. The Hong Kong office was closed in 2006 and its duties were taken over by the Shenzhen office. 
Table 1: Interviews with Expatriates

\begin{tabular}{|c|c|c|c|c|}
\hline Interviewees & Age (years) & $\begin{array}{c}\text { Time working in } \\
\text { the company }\end{array}$ & Time as an Expatriate & Position \\
\hline Expat 1 & 31 & 3 years & 7 months & Chief Representative Officer \\
\hline Expat 2 & 29 & 8 months & 3 and $1 / 2$ years & Asia Pacific Quality Manager \\
\hline Expat 3 & 25 & 2 and $1 / 2$ years & 6 months & Business Development Manager \\
\hline Expat 4 & 33 & 1 (one) month & 3 years & Manager \\
\hline
\end{tabular}

Source: Primary research data

The major roles of Intelbras' expatriates, at that time, were to oversee the quality of suppliers, negotiate with suppliers, search for new suppliers and conduct product development. Therefore, their main goal was to guarantee quality and competitive prices on the company's imported components.

An analysis of the company`s expatriate manual revealed that there was no specific focus on preparation for expatriation, but only on the rules and duties that govern the procedure. The expatriation manual provided detailed information regarding procedures and practices that each expatriate must agree to in order to be sent abroad. It also specified the responsibilities of the organization concerning its employees.

The high cost of expatriation (BLACK, 1988) was also evident in the manual, since it specified that employees sent abroad as expatriates would be entitled to a $40 \%$ increase in their monthly salaries, help with daily expenses varying from around US $\$ 50$ to US $\$ 70$, a one-time establishment payment of US $\$ 1,500$, a one-time technology purchase assistance of US\$1,800, and a ticket to return home once a year (INTELBRAS, 2011).

All these extra payments, when added up, represented a high cost for the organization. Thus, the management of expatriates is an area that the company cannot afford to overlook. It is important not only due to the role of the expatriates in the foreign country, but also because of the high cost of this activity.

The expatriation manual did not mention any repatriation program or policy (Tung, 1998), which usually leads to problems for expatriates in many firms. The analysis revealed that after the expatriate returns to company headquarters in Brazil, they return to their original salary, losing all the benefits to which they were entitled as expatriates (INTELBRAS, 2011). Moreover, the expatriates complained about the lack of information regarding the expatriation process. All the managers that were interviewed agreed that the company did not have clear rules and procedures for regulating the expatriation of its employees. However, they also recognized that the company was aware of the situation and sought to address it by proposing more attractive expatriation opportunities for its employees.

One of the most frequent complaints of the expatriates had to do with the time difference between Brazil and China and the lack of working procedures. The twelve-hour time difference and the lack of established procedures means that expatriated employees very often receive business telephone calls from Brazil late at night. This makes their work very tiring as they already have a busy workday. It also complicates communication between headquarters in Brazil and the company operations in China and communication between the expatriates and their extended families back in Brazil. These communication problems have led to difficulties concerning management, particularly concerning problem solving and decision making within the corporation.

The organization was identified by interviewees as not being very well organized when it comes to expatriation initiatives and progress on this matter was regarded as very slowly. It was clear that the company had not been very helpful in assisting its expatriates resolve the problems they were facing abroad.

The local Chinese employees were described by interviewees as being very helpful and friendly towards the expatriates, but they were unable to solve all their problems and see to all their needs. The lack of institutional support and structure to conduct their work abroad was identified by an expatriate as one of the main problems to be overcome.

The cultural difference was pointed out by all those interviewed as one of the most relevant barriers faced by Brazilian expatriates. Food, language and 
healthy hygiene habits were identified as being quite different from what they were used to in Brazil. All these cultural elements hindered the expatriates' adaptation to living and working in China.

One of the managers stressed that "smoking is permitted everywhere, and even in places where it is prohibited, the local people still smoke" (INTERVIEW EXTRACT). Another expatriated manager noted that "The Chinese spit and burp in public, which is initially quite shocking for a Brazilian" (INTERVIEW EXTRACT).

Furthermore, one of the expatriates had experienced health problems in China, and was taken to a local hospital. Although the hospital's infrastructure and technology were very modern, the manager was terrified by the hygiene, not only of the rooms but also of the nurses and doctors. The same manager was also shocked by Chinese medicine and how the Chinese view medical treatment, which is quite different from medical treatment in Brazil.

Another factor identified as a barrier to expatriates was the individualism of the Chinese people, which made integration between locals and expatriates more difficult. According to all the interviewees, the Chinese people were not particularly inclined to hold friendly conversations or even simply say hello. One manager claimed that "in the elevator you can see the individualism of the Chinese, because they do not hold the door when there is someone trying to come in, they do the opposite: They simply press the Close button" (INTERVIEW EXTRACT).

All the interviewees also complained about the traffic in China. They pointed out that the Chinese drive haphazardly and show no respect for traffic laws. As one of the managers stated: "it seems that every Chinese person in a car sets his own rules about how to drive" (INTERVIEW EXTRACT).
Another point that all the managers agreed upon was in relation to the internet restrictions imposed by the Chinese government. Being used to free internet access in Brazil, they are not used to having their internet searches limited. This is clearly a politically motivated situation, as the restricted access is a government decision.

Although China is undergoing a Westernization process (PAN et al, 2010), the local reality is still very much in contrast with the reality of Western countries. In mainland China, for instance, there is less western influence than what is seen in cosmopolitan cities such as Hong Kong and Shanghai, where the western influence is definitely stronger and more visible.

Despite the psychic distance, the expatriates perform their duties well, and the Brazilian headquarters of the company were pleased with their output in China. The company's international supply buyers were feeling that their role as buyers in the international markets was losing importance. This is because the expatriates working in China perform their tasks effectively and carry out their duties accordingly.

However, because of the psychic distance between Brazil and China, and especially the difference between living in an industrial city such as Shenzhen and living in Florianopolis, a pleasant coastal city in southern Brazil (where the Intelbras headquarters are located), the expatriates do not feel inclined to stay in China for longer periods, and always end up asking to return home.

The main problems faced by the expatriates are summarized in Table 2 . The data clearly illustrate the wide psychic gap between the Brazilian and Chinese realities that expatriates have to deal with in their daily life overseas.

Table 2: Main problems faced by expatriates

\begin{tabular}{|c|c|c|c|c|}
\hline Element & MANAGEMENT & Political & CoMmunication & Cultural \\
\hline $\begin{array}{l}\text { Perception of } \\
\text { expatriates }\end{array}$ & $\begin{array}{l}\text { 1. Lack of support and preparation } \\
\text { for expatriate activity in China. } \\
\text { 2. Lack of experience } \\
\text { managing expatriates }\end{array}$ & $\begin{array}{l}\text { 1. Government } \\
\text { restrictions on } \\
\text { internet use }\end{array}$ & $\begin{array}{l}\text { 1. Time difference. } \\
\text { 2. Internet restrictions }\end{array}$ & $\begin{array}{l}\text { 1. Large cultural distance between } \\
\text { Brazilian and Chinese culture. } \\
2 \text {. Westernization at a slow } \\
\text { pace in mainland China. }\end{array}$ \\
\hline
\end{tabular}

Source: Primary research data 
The expatriate experience provided valuable insight when it comes to increasing the company's presence in the global market, by expanding new possibilities in terms of supplying (ZOOGAH; ABBEY, 2010; BRANNEN; THOMAS, 2010). The performance of the expatriates actually did allow the company to expand its supplying options not only in China, but also in other countries in South East Asia. However, the lack of administrative structure and organizational support for expatriate activities abroad might still represent an internal weakness and a challenge to be overcome.

\section{Discussion}

As the company increased its internationalization in China, the number of expatriate managers also expanded, from one to four, establishing a direct relationship between the two variables. This outcome confirms the studies of Delios and Bjorkman (2000) and refutes the results achieved by Tan and Mahooney (2006) and Ando (2011).

The lack of administrative structure and organization to support expatriate activities abroad might represent a major liability for the organization. To Chew (2004), the lack of organization involving expatriates can create problems locally that are difficult and costly to manage, including public relations and legal procedures.

The company's lack of international experience is one of the main reasons behind this problem. Not only does the company not have international experience, but neither do its executives. They are not very familiar with international business activities or their requirements in terms of resources, network and investments. All of these factors are evidence of a lack of experience in expatriate management.

The cultural differences between Brazilians and Chinese people constituted another element to be considered, since all the expatriates interviewed voiced complaints in this respect. In this situation, there is a clear cultural shock between Brazilian culture, where people are sociable and open to interpersonal interactions (DOMINGUES; BUENO, 2008), and Chinese culture, where people are known for being less open to interpersonal relations and taking more time to develop trust in other people.
But more than cultural differences, there is strong evidence of a psychic distance (JOHANSON; VAHLNE, 1977) between Brazilian and Chinese politics, administration and culture, which proves that the adjustment of Brazilians to the Chinese reality tends to be more complicated. Brazilian and Chinese people are not only distant culturally but also psychically. The two countries are quite different not only in terms of culture but also in political and sociological terms. Indeed, they are two different countries that underwent quite distinct civilization processes.

This is especially true when drawing a comparison between the location of Intelbras' headquarters and its Chinese office. The comparison indicated that it is almost inevitable that the expatriates will express a desire to return to the company's headquarters in Brazil. This is one of the reasons behind the widening psychic distance, and an important factor to be addressed when dealing with expatriates.

The change in the location of Intelbras' Chinese office from Hong Kong to Shenzhen, despite moving employees closer to their suppliers, also helped to increase the psychic distance in the eyes of the expatriates. Hong Kong is a busy, lively cosmopolitan coastal city, whereas Shenzhen is a big business town without major attractions.

Thus, it would be critical for the organization to establish a program to prepare its employees prior to their departure in order to develop activities and provide information about the other country to mitigate the impact of the psychic distance (HOFSTEDE, 1980; BLACK, 1988; DUNBAR; KATCHER, 1990; BLACK; MENDENHALL, 1990; TUNG, 1998; SHAFFER; HARRISON; GREGERSEN; BLACK; FERZANDI, 2006). This would be a strategic initiative since difficulty in dealing with psychic distance (SHIH; CHIANG; HSU, 2010; PATTIE; PARKS, 2011) can become one of the main causes of expatriate failure, with implications for the long-term outcomes of the company abroad.

Tung (1995), in her research on expatriates, found that cultural differences were not a problem when it came to expatriate performance and at Intelbras, this was especially true. Although the expats complained about the cultural differences and the existence of the effects of the psychic distance, the managers carried out their activities and continued to present good performance. 
The challenges facing the adaptation of expatriates and their families in China also require a deeper and broader understanding at company headquarters in order to facilitate their adaptation and attempt to reduce the psychic distance. On this matter, authors such as Hofstede (1980), Andreason (2008), Cole (2011), Harvey, Napies and Moeller (2009), Kupka and Cathro (2007), Chew (2004), Shaffer and Harrison (1998) and Harvey (1998) have stressed that the non-adaptation of expatriates' families is usually a strong reason for them failing in their duty.

Culture is something subtle that emerges on the surface on a daily basis and most of the time it is also difficult to understand unless one is immersed in the cultural context. Consequently, to understand a foreign culture and attempt to reduce the psychic distance between two countries, it is important to select expatriate candidates that are more familiar with the overseas culture they will face (HOFSTEDE, 1980; MEYER; MEYER; KRETZER-SANTOS, 2009; BRANNEN; THOMAS, 2010; DONG; LIU, 2010).

Expatriation is a costly investment for any organization (MCNULTY; DE CIERI; HUTCHINGS, 2009). Therefore, it is important that a specific program be developed to select and prepare the right people for key positions abroad. Expatriate programs are usually more popular among multinational companies, and approaches can be imported from other companies' settings without major problems.

Nevertheless, this is becoming an even more strategic issue as the company increases its internationalization and expands the number of expatriate managers, (DELIOS; BJORKMAN, 2000). The more structured and organized the expatriation program is, the better the results will be, since expats will be better prepared to face the challenges of living and working in a different country.

\section{Concluding Remarks}

The role and preparation of expatriates being sent to work abroad by companies is becoming a growing and important managerial process that may contribute to the performance of companies overseas. The findings have shown that the psychic distance that Brazilian expatriate executives face in their Chinese missions is a major problem to be overcome by the company in order to achieve sustainable and effective long-term operations in China.

The distance between Brazil in China is not only cultural but also to a large extent psychic. Both are emerging economies and share some similar foreign policy interests, but in terms of administrative, political and cultural differences, the distance is quite large and represents a major issue for the company's expats.

China is now Brazil's major trading partner. The international business between the two countries is growing in such a way that it is becoming necessary for companies to have a better understanding of the challenges they face and develop concrete strategic actions to help them adjust to the economic, social, political, cultural and psychological factors embedded in each other's context.

Brazilian multinational companies, as late movers in the international markets, are still learning how to develop their own way of operating in foreign markets. This could be one of the reasons why there are few studies on Brazilian companies operating in China, especially studied focusing on people and their adaptation to daily life in China.

This case study provided evidence that there is a significant psychic distance between the two countries and this may be a major obstacle for the adaptation of expatriate executives. Therefore, this is a strategic component, and Brazilian and Chinese multinational corporations must address it before implementing internationalization strategies.

During the development of this study, some topics were mentioned or not deeply explored since they are not part of the central focus of the study. These themes require further, in-depth studies with implications for both the theoretical and practical dimensions.

Future research in the field of internationalization and the role of expatriate management could concentrate on the performance of Brazilian companies abroad, with a special focus on programs and activities devoted to the preparation of professionals to function effectively in different social, political and cultural contexts. Longitudinal studies based on the experience of a group of expatriates overseas may produce valuable and important data by examining both the factors and barriers faced by expatriates and their families, as well as strategies to adjust to different contexts with implications for individual and organizational performance. 


\section{REFERENCES}

ANDO, N. Isomorphism and foreign subsidiary staffing policies. Cross Cultural Management: An International Journal, [S.l.], v. 18, n. 2, p. 131-143, 2011.

ANDREASON, A. W. Expatriate adjustment of spouses and expatriate managers: an integrative research review. International Journal of Management, [S.I.], v. 25, n. 2, 382-395, 2008.

BLACK, J. S. Work role transitions: a study of American expatriate managers in Japan. Journal of International Business Studies, [S.I.], v. 19, n. 2, p. 277-294, 1988.

BLACK, J. S.; MENDENHALL, M. Cross-cultural training effectiveness: a review and theoretical framework for future research. Academy of Management Review, [S.l.], v. 15, n. 1, p. 113-136, 1990.

BRANNEN, M. Y.; THOMAS, D. C. Bicultural Individuals in Organizations: implications and opportunity.

International Journal of Cross Cultural Management, [S.l.], v. 10, n. 5, p. 5-16, 2010.

CALIGIURI, P. M.; TUNG, R. L. Comparing the success of male and female expatriates from a US-based multinational company. The International Journal of Human Resources Management, [S.l.], v. 10, n.5, p. 763-782, 2001.

CHEW, J. Managing MNC expatriates through crises: a challenge for international human resource Management. Research and Practice in Human Resource Management, [S.l.], v. 12, n. 2, p. 1-30, 2004.

COLE, N. D. Managing global talent: solving the spousal adjustment problem. The International Journal of Human Resource Management, [S.l.], v. 22, n. 7, p. 1.504-1.530, 2011.

CRESWELL, J. W. Research design: qualitative, quantitative, and mixed methods approaches. Thousand Oaks: Sage Publications, 2009.

DELIOS, A.; BJORKMAN, I. Expatriate staffing in foreign subsidiaries of Japanese multinational corporations in the PRC and the United States. International Journal of Human Resource Management, [S.I.], v. 11, n. 2, p. 278-293, 2000.
DOMINGUES, C. R.; BUENO, J. M. Gestão internacional e cultura nacional brasileira. Revista Brasileira de

Estratégia, [S.l.], v. 1, n. 1, Jan./Abr., p. 89-105, 2008.

DONG, K.; LIU, Y. Cross cultural management in China.

Cross Cultural Management: an International

Journal, [S.l.], v. 17, n. 3, p. 223-243, 2010.

DUNBAR, E.; KATCHER, A. Preparing managers for foreign assignments. Training \& Development Journal, [S.l.], v. 44, n. 9, p. 45-47, 1990.

EISENHARDT, K. M. Building theories from case study research. Academy of Management Review, [S.I.], v. 14, n. 4, p. 532-550, 1989.

FRANCISCO, J. M. S. D. Internacionalização para um mercado culturalmente próximo, mas em Guerra: a Odebrecht em Angola. In: XXVIII EnANPAD 2004, Curitiba. Anais..., Curitiba, ANPAD, 2004. p. 54-72.

GODOY, A. S. Estudo de caso qualitativo. In: GODOI, C. K.; BANDEIRA-DE-MELLO, R.; SILVA, A. B. (Org.). Pesquisa qualitativa em estudos organizacionais: paradigmas, estratégias e métodos. São Paulo: Saraiva, 2007. p. 115-146.

HARVEY, M. Dual-career couples during international relocation: the trailing spouse. International Journal of Human Resource Management, [S.I.], v. 9, n. 2, p. 309-331, 1998.

HARVEY, M.; NAPIER, N.; MOELLER, M. Interpreting dual career couples' family lifecycles: identifying strategic windows of global career opportunity. Research and Practice in Human Resource Management, [S.l.], v. 17, n. 2, p. 14-35, 2009.

HOFSTEDE, G. Culture's Consequences: international differences in work-related values. Beverly Hills: Sage Publications, 1980.

\section{INTELBRAS. Política para expatriação de} colaboradores. São José: Abril 20th, 2011.

JACCOUD, M.; MEYER, R. A observação direta e a pesquisa qualitativa. In: POUPART, J. et al. A pesquisa qualitativa: enfoques epistemológico e metodológicos. Petrópolis: Vozes, 2008 
JOHANSON, J.; VAHLNE, J. The internationalization process of the firm: a model of knowledge development and increasing foreign market commitments. Journal of International Business Studies, Hampshire, n. 8, Spring, p. 23-32, 1977.

KUPKA, B.; CATHRO, V. Desperate housewives: social and professional isolation of German expatriated spouses.

The International Journal of Human Resource

Mangement, [S.l.], v. 18, n. 6, p. 951-968, 2007.

MCNULTY, Y.; DE CIERI, H.; HUTCHINGS, K. Do

global firms measure expatriate return on investment? An empirical examination of measures, barriers and variables influencing global staffing practices. The International

Journal of Human Resource Management, [S.I.], v. 20, n. 6, p. 1.309-1.326, 2009.

MEYER, V., Jr.; MEYER, B. MURPHY, J. P. The influence of culture in international business. In: XXX EnANPAD, 2006,Salvador. Anais... Salvador: ANPAD, 2006. p. 95121.

MEYER, V. Jr.; MEYER, B.; KRETZER-SANTOS, E. Estratégia e cultura na internacionalização da educação superior: a experiência da Universidad de la Integración de las Américas. Revista de Negócios, [S.1.], v. 14, n. 3, p. 72-83, 2009.

PAN, Y. et al. A cross-cultural investigation of work values among young executives in China and the USA. Cross

Cultural Management: An International Journal, [S.l.], v. 17, n. 3, p. 283-298, 2010.

PATTIE, M.; PARKS, L. Adjustment, turnover, and performance: the deployment of minority expatriates.

The International Journal of Human Resource

Management, [S.l.], v. 22, n. 10, p. 2.262-2.280, 2011.

REMENYI, D. et al. Doing research in business and management. London: Sage Publications, 1998.

ROWLEY, C.; BENSON, J. Convergence and divergence in Asian human resource management. California Management Review, [S.l.], v. 44, n. 2, p. 90-109, 2002.

SHAFFER, M. A.; HARRISON, D. A. 'Expatriates' psychological withdrawal from international assignments: work, nonwork, and family influences. Personnel

Psychology, [S.l.], v. 51, n.1, p. 87-118, 1998.
SHAFFER, M. A. et al. You can take it with you: individual differences and expatriate effectiveness. Journal of Applied Psychology, [S.l.], v. 91, p. 109-125, 2006.

SHIH, H.; CHIANG, Y.; HSU, C. High involvement work system, work-family conflict, and expatriate performance: examining Taiwanese expatriates in China. The International Journal of Human Resource Management, [S.l.], v. 21, n. 11, p. 2.013-2.030, 2010.

TAN, D.; MAHONEY, J. T. Why a multinational firm chooses expatriates: integrating resource-based, agency and transaction costs perspectives. Journal of Management Studies, [S.I.], v. 43, n. 3, p. 457-484, 2006.

TUNG, R. L. American expatriates abroad: from neophytes to cosmopolitan. Journal of World Business, [S.l.], v. 33, n. 2, p. 125-144, 1998.

YIN, R. K. Applications of case study research. Newbury Park: Sage Publications, 1993.

ZOOGAH, D. B.; ABBEY, A. Cross-cultural experience, strategic motivation and employer hiring preference: An exploratory study in an emerging economy. International Journal of Cross Cultural Management, [S.l.], v. 10, n. 3, p. 321-343, 2010. 